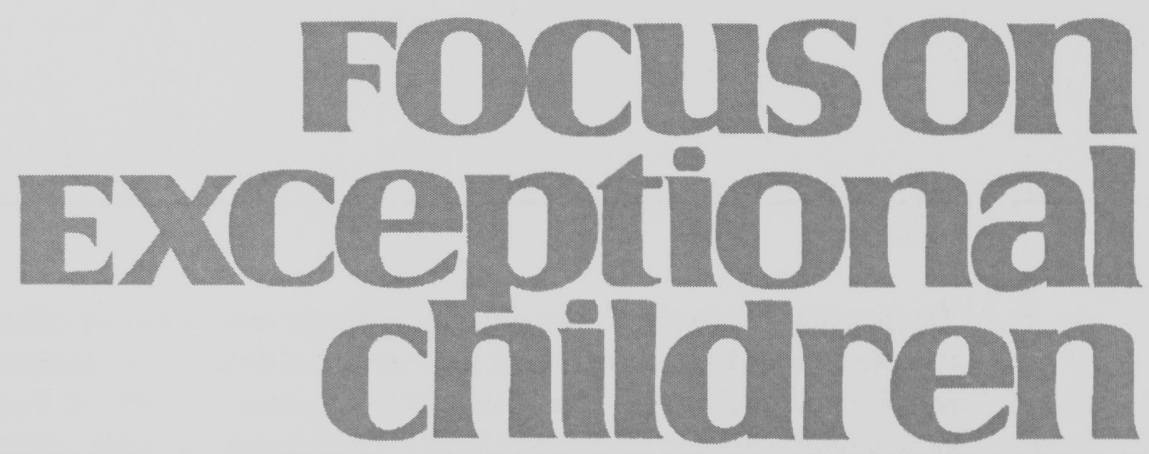

\title{
A Modest Proposal in Four Parts
}

\author{
H. Rutherford Turnbull, III
}

\section{A MODEST PROPOSAL}

Jonathan Swift, Dean of St. Paul's Cathedral, London, wrote a famous essay that I invoke now. In A Modest Proposal, Swift (1729) satirically suggested that, for more Irish to live longer during a current famine, adults should eat their newborns, thus feeding the more able while preventing a population growth that would exacerbate the famine.

I, too, wish to make a modest proposal, to justify it historically, and to relate it to contemporary and future issues in special education. Unlike Swift, I am serious, not satirical. Unlike Swift, I do not address a problem of physical famine but, instead, a problem of hunger for a more productive system of education for all students. And, again unlike Swift, I do not expect my proposal to be acted upon, although I believe it has the merit of challenging a conventional approach in education, which is that general education policy should affect, but not be much affected by, special education policy (West \& Whitby, 2008).

\section{Data and Famine of a Sort}

Data from the National Center for Education Statistics (NCES) lie at the basis of any reform of education policy. They are both encouraging and discouraging. (The data in bulleted items 1 through 8 are from the NCES, 2009.)

- Enrollment in school rises over time, younger students perform better over time, but secondary school students' performance levels have not risen over time (NCES, Introduction, 2009).

- Between 1972 (2 years before Congress enacted PL 94-142, the Education for All Handicapped Children Act) and 2007, the percentage of white public school students decreased by $22 \%$; the percentage of students from other racial/ethnic groups increased by $22 \%$, largely because of an increase in Hispanic students and a decrease in black students.

- Between 1979 and 2007, the percentage of school-aged children (ages 5-17) whose parents had earned a bachelor's or higher degree increased by $16 \%$, but the increase was greater for white parents (22\%) than for black parents $(16 \%)$ or Hispanic parents $(8 \%)$.

\footnotetext{
Mr. Turnbull is a Distinguished Professor and the Cofounder and Codirector of the Beach Center on Disability at the University of Kansas, Lawrence.
} 
- The percentage of school-aged children living in twoparent households decreased in that same period of time by $8 \%$ and now holds constant since 1995 at between $67 \%$ and $69 \%$. Higher percentages $(65 \%)$ of white children live in two-parent households than do their black peers $(35 \%)$. In $2006,50 \%$ of black students lived in mother-only households, but only $25 \%$ of Hispanic students did and only $26 \%$ of white students did.

- A larger percentage of children were living in poor households in 1979 than in 2006 (17\% vs. 15\%). In 2006 , the percentage of white children in poverty households was $10 \%$; of black children, $33 \%$; and of Hispanic children, $26 \%$.

- The birthrate of children in Hispanic homes increased by $5 \%$ between 1995 and 2006; the birth rate of white and black students remained unchanged. In 2007, approximately $20 \%$ of children ages $5-17$ spoke a language other than English at home, an increase from $9 \%$ to $20 \%$ between 1979 and 2007. Variables affecting language-minority children included race/ethnicity, poverty status, and age.

\section{Focuson
Exceptional children}

ISSN 0015-511X FOCUS ON EXCEPTIONAL CHILDREN (USPS 203-360) is published monthly except June, July, and August as a service to teachers, special educators, curriculum specialists, administrators, and those concerned with the special education of exceptional children. This publication is annotated and indexed by the ERIC Clearinghouse on Handicapped and Gifted Children for publication in the monthly Current Index to Journals in Education (CIJE) and the quarterly index, Exceptional Children Education Resources (ECER). The full text of Focus on Exceptional Children is also available in the electronic versions of the Education Index. It is also available in microfilm from Serials Acquisitions, National Archive Publishing Company, P.O. Box 998, Ann Arbor, MI 48106-0998. Subscription rates: individual, \$48 per year; institutions, \$66 per year. Copyright @ 2009 , Love Publishing Company. All rights reserved. Reproduction in whole or part without written permission is prohibited. Printed in the United States of America. Periodical postage is paid at Denver, Colorado. POSTMASTER: Send address changes to:

$$
\begin{gathered}
\text { Love Publishing Company } \\
\text { Executive and Editorial Office } \\
\text { P.O. Box } 22353 \\
\text { Denver, Colorado } 80222 \\
\text { Telephone (303) 221-7333 }
\end{gathered}
$$

\section{EDITORIAL BOARD}

Steve Graham Vanderbilt University
Ron Nelson University of Nebraska-Lincoln

Eva Horn

University of Kansas

Carrie E. Watterson

Senior Editor
Stanley F. Love

Publisher
- The number of children receiving special education increased annually since 1976-77 through 2004-05. From 2004-05 through 2006-07, however, the number decreased annually. Today, approximately $9 \%$ of all school-aged children are served in special education. In $2006-07,59 \%$ of them were white, $20 \%$ were black, $17 \%$ were Hispanic, and $3 \%$ were Asian/Pacific Islander or Indian/Alaska Native.

- Since 1980-81, a larger percentage of students ages 3-21 have received special education because of a specific learning disability than for any other type of disability. In 2006-07, approximately $47.4 \%$ of all students receiving special education had a specific learning disability and $18.7 \%$ had a speech-language disability (U.S. Department of Education, 2007).

- Approximately $3 \%$ to $8 \%$ of the general population has ADHD (Biederman, 2005; Smith, Barkely, \& Shapiro, 2007), with a prevalence rate of $4.2 \%$ for preschoolers (Egger, Kondo, \& Angold, 2006). Approximately $40 \%-80 \%$ of children identified as having ADHD persist in displaying the disorder into their secondary school years (Smith et al., 2007).

These data reflect at least two trends relevant to my modest proposal. First, disability correlates positively on the one hand with race/ethnicity, language, poverty, and family structure on the other.

\footnotetext{
Five "ecological layers" affect students experiencing the comorbid factors of disability, race/ethnicity, language, and poverty, family factors, school factors, community factors, state and federal policy factors, and majority cultural factors. Clearly, disproportionality in special education placement needs to be understood within the context of disproportionality in society.... To ensure equal opportunities for students from culturally diverse backgrounds, it is necessary to provide not only culturally responsive instruction of students, but also culturally responsive support of families, culturally responsive support of schools, culturally responsive community living, culturally responsive state/federal policy, and culturally diverse societal values. (Turnbull, Turnbull, \& Wehmeyer, 2010, p. 84, 87)
}

The second factor is that, although the number of students served in special education has remained relatively constant, the percentage of students served because of a specific language disorder, speech-language impairment, or ADHD has increased.

My modest proposal speaks to the comorbidity factors of disability, race/ethnicity, language, and poverty, especially as they are reflected in the data about single-family households (NCES, 2009; Turnbull et al., 2010). It also addresses the "spread" effect in special education-the tendency of special education services to be made available to an increasingly large cohort of students with SLD, SPLH, and 
ADHD challenges. In both respects, my modest proposal reflects my belief that special education stigmatizes a student even while it benefits the student (Turnbull \& Wheat, 1983; Turnbull et al., 2007; Turnbull et al., 2010). Bearing in mind the comorbidity and spread factors, I propose that Congress should

- re-align special and general education laws by aligning No Child Left Behind Act (NCLB is now referred to as Elementary and Secondary Educaton Act [ESEA] because NCLB was an amendment of that statute) with IDEA-reverse the present alignment;

- target particularly the students most affected by the comorbid factors of disability, race/ethnicity, language, poverty, and family structure-restore the civil rights mission in education;

- target particularly those students so affected who are in secondary schools-focus on those students before the leave school altogether; and

- create a new category of education, entitled supported education, that is part of general education but that adopts many of the practices of special educationtrifurcate what is now a bifurcated system.

Data are not the only factors driving my proposal. History has its role, too.

\section{ORIGINAL PROBLEMS AND ORIGINAL SOLUTIONS IN SPECIAL EDUCATION POLICY}

When Congress enacted PL 94-142, the Education for All Handicapped Children Act in 1975, it addressed problems that have largely, if not perfectly, been resolved. In brief, there were two major problems. The first was exclusion, either "pure" exclusion, not admitting students to any program of education, or "functional" exclusion, admitting them but not offering real benefit (Turnbull et al., 2007). The second was misclassification, either placing students into special education who did not have a disability or placing some into special education but in the wrong "category" or population of people with disabilities (Turnbull et al., 2007).

Additional problems included the lack of appropriate public education for those allowed to attend schools, the segregation of students with disabilities from those without disabilities, the lack of means for parents to participate in making decisions about their children's education, and the lack of means for parents to hold schools accountable for their decisions and behaviors (Turnbull et al., 2007).

\section{The Brown Effect}

In 1975, Congress had not participated in state and local school decision-making in any significant way other than by enforcing the Supreme Court's integration decision, Brown v. Topeka Board of Education (1954), and subsequent cases. In response to Brown, Congress enacted the Civil Rights Act of 1964 (PL 102-166, 42 U.S.C. Sec. 1971), authorizing federal intervention in education to enforce the Fourteenth Amendment's amendment's equal protection (equal educational opportunity) guarantee. That is significant because Congress' concerns in enacting PL 94-142 were clearly also race-based. Exclusion and misclassification-particularly misclassification - had fallen more heavily on racial minority students with disabilities than on other students. Just as Brown impelled Congress to enact the Civil Rights Act, so, too, had several federal court decisions (Larry P. v. Riles, 1972; PASE v. Hannon, 1980), attacking special education placement because of its disparate impact on minority students, impelled it to enact and then strengthen the nondiscriminatory evaluation provisions in PL 94-142 (Turnbull et al., 2007). In a word, PL 94-142 was a civil rights law in two respects: first, to enforce the rights of students with disabilities, and, second, to desegregate special education by race (Turnbull et al., 2007). In that posture, PL 94-142 aligned with the Civil Rights Act, which is to say that it was not explicitly aligned with ESEA except by reason of the fact that it made permanent the ESEA's weak special education provisions enacted in 1966 (PL 89-750), 1970 (PL 91-230), and 1974 (PL 93-380).

\section{The Challenge of Alignment}

Not until 2002, when it enacted NCLB (PL 107-110), and 2004, when it reauthorized IDEA (PL 108-446), did Congress again seriously connect general education and special education laws. It did so by responding to criticisms (Finn, Rotherham, \& Hokanson, 2002; President's Commission on Excellence in Special Education [PCESE], 2003) that (1) special education was teaching students to be "dependent" on a lifetime of support and (2) special education was underperforming in nine different respects. In the 2004 reauthorization, Congress restated the law's purposes, including assuring equal opportunities in education-the very point of the Brown decision (20 U.S.C. 1401(d)). Having found that low expectations about students with disabilities and teachers' failure to use proven methods of teaching were the two barriers to assuring a more effective special education, Congress then set out eight solutions to these two barriers (20 U.S.C. Sec. 1401(c)). Among them was aligning IDEA and NCLB. The alignment was less than perfect because the six principles of each of these two laws varied (Turnbull et al., 2007). But modest alignment is insufficient. It is time to remake history, especially bearing in mind the data I have cited.

\section{Modest Proposal in Four Parts}

As I said above, I propose a four-part approach. 
First, Congress should use IDEA, not NCLB, as the lead law for alignment. That is, Congress should amend IDEA to strengthen it, and then align NCLB with it. If Congress were to do so, it would entirely reverse the alignment that presently exists.

Second, by aligning NCLB with IDEA, Congress should specially target the students from ethnic, linguistic, and culturally diverse backgrounds ("diverse" backgrounds) and from environments that have factors correlated positively with disability ("comorbid" environments). It is time to restore the civil rights movement within education.

Third, within that special target, Congress should especially take into account the students in secondary schools.

Fourth, Congress should authorize a third type of education, called "supported education." It is time to abandon the bifurcated model and adopt a trifurcated model.

My not-so-modest proposal makes sense for compelling reasons, even though - and perhaps because - the conventional wisdom has been (Finn et al., 2001; PCESE, 2002) and still seems to be to align special with general education (West \& Whitby, 2008).

\section{CURRENT SPECIAL POPULATIONS AND ASYMMETRICAL BUT COORDINATED ATTACKS ON CAUSES}

\section{Disproportionate Representation}

When Congress enacted PL 94-142, it was acutely aware of the disproportionate representation of minority students in special education and of the fact that the skewed representation was resegregating schools on the basis of race, contrary to the Supreme Court's decision in Brown and the Civil Rights Act of 1965. Nowadays, data from NCES and OSEP continue to reflect the disproportionate representation of students from "diverse" backgrounds (race/ethnic, language/linguistic, and cultural minority populations) in special education. When Congress reauthorized IDEA in 2004, it restated its concerns with disproportionate representation, yet it did little to address the matter frontally (20 U.S.C. Sec. 1401(c)). It left largely untouched the provisions for a student's nondiscriminatory evaluation, and it mentioned homeless and migrant students but did little within IDEA to address their needs other than to assure their access to special education. In short, Congress failed to address powerfully enough two issues: comorbidity, and inter-agency/service-system collaboration and cooperation.

\section{Comorbidity}

It is well established that disability is correlated positively with poverty, ethnic-cultural-linguistic diversity, family structure, and place of residence (Ong-Dean, 2009; Turnbull et al., 2010; Swanson, 2008; U.S. Department of Education, 2007, 2009). Environment exerts a powerful influence on students and their outcomes and schools and their effectiveness. Educators can do much to mitigate the negatives of a student's contexts, but they cannot do everything. In a word, context controls. The "ecological" analysis that Turnbull et al. (2010) bring to the matter of comorbidity begs for action at five levels. In this modest proposal, I focus on only the federal policy environment.

\section{Collaboration and Cooperation}

As powerful as any one or a combination of school interventions are, they will be insufficient to change the outcomes of students with disabilities and even students without disabilities who "present" within the comorbid spectrum. That is so because schools have limited power to address the factors of comorbidity. Their funding, mission, governance, infrastructures, and professional capacities are limited, and, historically and even now, justifiably so.

Unless, however, federal, state, and local governmental agencies, in cooperation with NGOs and faith-based entities, collaborate to attack directly and powerfully the factors that contribute to comorbidity and thus disability, there will be little that schools can do, alone, to blunt the factors' effects on general education and special education students. Alignment of special and general education with health, mental health, social service, public safety, housing, and jobs agencies is necessary and has been proven to be effective. Rising tides in those areas of public service should lift all boats, but targeted efforts are needed in the school districts where there is the highest incidence of the factors that correlate with disability. Further, given the dismal data about secondary school students (Schumaker et al., 2002), especially those from "diverse" populations and "challenged" environments (Ong-Dean, 2009; Swanson, 2008; Turnbull et al., 2010), particular efforts in those school districts should focus on students entering secondary-school programs. I suggest three modest strategies for all schools but, being realistic, realize these must be made even more modest by being applied to only the schools, especially secondary schools, where the comorbidity is greatest:

1. Create multi-purpose (secondary) schools with health, social service, juvenile diversion, drug-alcohol counseling, conflict resolution, and related services.

2. Target these services to the dominant factors within the comorbid spectrum that most often affect a school or school district (since not all schools and districts experiencing comorbidity are alike).

3. Offer training stipends with reduced pay-back obligations to any general or special educator or 
other professional from one of these service professions who works in these schools for a designated period of time.

To make it more possible for all students in low-income public schools to receive collaborative and coordinated service systems, federal, state, and local policy makers and administrators must lower the height of the silos and shrink the distance between them. IDEA provisions move general and special education into closer relationships; especially salient are those related to

- memoranda of understanding between juvenile justice and education agencies (20 U.S.C. Sec. 1412(a)(11) (C)),

- memoranda of understanding between healthcare (Medicaid) and education agencies (20 U.S.C. Sec. 1412),

- multidisciplinary and often interagency evaluation of students (20 U.S.C. Sec. 1414(a)-(d)), and

- provision of related services to assure them an appropriate education (20 U.S.C. Sec. 1414(d)).

In aligning NCLB under IDEA, Congress should provide for interagency, multidisciplinary, and beefed-up educational services (including related services) for general education students, especially those in secondary schools in areas particularly affected by the comorbidity phenomenon. These structural changes, however, should be just the beginning of a different alignment. The next stage in the different alignment is to import into general education the six principles that have driven special education policy since 1975 (Turnbull \& Turnbull, 1978; Turnbull et al., 2007).

\section{FOR A MORE PERFECT ALIGNMENT: APPLYING IDEA'S SIX PRINCIPLES TO GENERAL EDUCATION}

IDEA's six principles consist of four input principles (zero reject, nondiscriminatory evaluation, appropriate education, and least restrictive education) and two accountability principles (procedural due process and parent participation). NCLB's six principles (Turnbull et al., 2007) shadow but do not exactly mirror IDEA's principles. NCLB's principles are accountability, highly qualified teachers, evidencebased interventions (these three relate to IDEA's appropriate education principle), school safety (this relates to IDEA's zero reject principle), parent participation (this relates to IDEA's principle of the same name), and local flexibility (with respect to funding, a tightly limited opportunity within IDEA, 20 U.S.C. Sec. 1412 \& 1413). Under my modest proposal, IDEA's six principles would preserve some NCLB principles, modify others, and add still others.

\section{The Zero Reject Principle and Discipline.}

Under IDEA, the general rule is that a state or local education agency (SEA/LEA) may not totally terminate the education of a student who is disciplined for more than 10 days (20 U.S.C. Sec. 1415(b)). Whenever an LEA imposes "long-term" discipline, it must continue to educate the student; it also must determine whether the student's behavior is a manifestation of the student's disability and, if it is, consider conducting a functional behavioral analysis and developing a behavioral intervention plan (20 U.S.C. Sec. 1415(k)). IDEA's no cessation rule further prevents an LEA from terminating a student's education even if the student violates the "no guns, no drugs, no serious bodily injury" rule (20 U.S.C. Sec. 1415(k)). The LEA must still educate the student and may do so in an appropriate alternative education setting (IAES) (20 U.S.C. Sec. 1415(k)). NCLB lacks a "no cessation" principle; general education students may be totally deprived of an opportunity to learn while they are being disciplined. Indeed, the school-safety laws often terminate the education of the very students who arguably need it most. Although exclusion may offer degrees of safety to faculty and staff, it also regards the disciplined student as unworthy of being educated and arguably contributes to drop-out rates and failure-to-graduate results that particularly affect racial, ethnic, cultural, and linguistic minority populations. Further, absent the use of school-wide positive behavioral supports (SWPBS) and individualized functional behavioral assessments/analyses (FBA) and behavioral intervention plans (BIP), educators of students in general education often lack sufficient information about why the general education student acted in such a way as to provoke discipline and, thus, why and how to intervene to change the behavior.

Although the no cessation rule may have limits as applied to general education students who violate the guns-drugsinjury rule, the no cessation idea is appealing in general education, for it will blunt the long-term harmful effects of no education, especially for students whose choices-weapons, drugs, injury-are correctable through education and especially for students in the areas particularly affected by comorbid factors. In short, NCLB should reflect IDEA's zero-reject and discipline provisions, especially with respect to PBS, FBA, and BIP, and should do so particularly at the secondary school level.

\section{The NDE Principle}

Under IDEA, an SEA/LEA must assess a student in four domains: cognitive (academic), developmental, functional, and mental-emotional (20 U.S.C. Sec. 1414 (b) \& (d)). NCLB 
requires no comparable whole-child evaluation of a general education student. Often, however, the reasons general education students struggle in school, drop out, or are disciplined have little to do with their cognitive abilities and much to do with other domains of their development and the environments from which they come. Again, IDEA should drive NCLB, which should provide for whole-child, nondiscriminatory assessments for all children, especially secondary-level students from comorbid environments. Without knowing about the whole child, educators will be short-changed in teaching them and intervening in factors that affect their learning.

\section{The Appropriate Education Principle}

Under IDEA, an SEA/LEA must offer an individually tailored education (20 U.S.C. Sec. 1414(d)), and, under the Supreme Court's decision in Board of Education v. Rowley (1982), the curriculum and instruction that constitute that kind of education must be reasonably calculated to offer a genuine opportunity for the child to benefit. The appropriate education principle correlates with NCLB's principles of accountability, highly qualified teachers (HQT), and evidence/researchbased interventions (EBI). Indeed, the principle of accountability subsumes the other two principles; it is the end point, as measured by student proficiency on state and local assessments and as enabled by highly qualified teachers and their use of research-based interventions. Undoubtedly, NCLB's accountability provisions, as applied to IDEA-qualified students, have had benefits for general and special education students (Swanson, 2008). They have demonstrated that all of those students can achieve high standards if they are properly instructed and supported and if they are expected to achieve. They have reduced the achievement gaps between students with and without disabilities, especially in the elementary and middle-school years. They have assisted students with disabilities to make academic gains, but they have not yet sufficiently closed the gap between students from "diverse" and comorbid environments, especially those at the secondaryschool level (U.S. Department of Education, 2007). The accountability, HQT, and RBI principles are just starting points for the radical realignment that I modestly propose. That is so because special education techniques must be deliberately infused into the general education methods. Among the contributions that special education has made to children with disabilities are interventions that certainly can benefit students without disabilities. They include Response to Intervention, Positive Behavior Support, Universally Designed Learning, Differentiated Instruction, Assistive Technology, and books accessible in their format to all students, especially those with visual impairments.

Beyond these elements of an appropriate education, IDEA requires SEAs and LEAs to offer "related services" that are necessary for the child to benefit (20 U.S.C. Sec. 1414(d)). NCLB contains no similar standard (opportunity to benefit) and compels no similar necessary related services. IDEA's related services provision has made schools into multi-service entities. Taken together with the nondiscriminatory evaluation, appropriate education, and leastrestrictive environment provisions, these provisions have contributed to higher graduation/certificate of completion rates and improved postsecondary outcomes, though they have not blunted the drop-out rates (West \& Whitby, 2008) or mitigated the "school effect" that often relates to students' comorbid environments (Ong-Dean, 2009; Swanson, 2008). Some general education programs do indeed offer services other than "pure" education-the "school-linked" model-but NCLB does not require them to do so, nor does it compel the services to be individualized to a student. The national data on low-performing schools are showing some, but not adequate, NCLB-related gains for all general education students, including those from "diverse" and comorbid environments, while the results from IDEA are showing strong increases in academic performance (Swanson). Indeed, data suggest that the performance of students with disabilities is, in some cases, distributed across the continuum of academic achievement; the lowest-performing students in some schools and districts are not necessarily the students with disabilities, and some of those students are among the highest-performing students (West \& Whitby). Taken as a whole, data about general education students and about special education students suggest that what works under IDEA should be applied to NCLB. Again, IDEA should drive NCLB, and Congress should require schools-especially secondary schools serving "diverse" comorbid students-to offer related services and the techniques of teaching and learning that special education researchers and practitioners have shown to work.

\section{The LRE Principle}

Under IDEA, an SEA/LEA must offer a student an education in the "least restrictive environment" and, to that end, must determine what "supplementary aids and services" the general educators need to accommodate the student (20 U.S.C. Sec. 1414(d)). NCLB contains no requirement for supplementary aids and services. Yes, it requires educators to be highly qualified and to use research-based interventions, but it does not compel the services they may need to be effective for all-repeat: all - students. I favor educating these students in the general education curriculum, not in special education. The "supported education" program - an integral part of the general education program but augmented by practices in special education-will allow them to retain much of the benefit of supported education if they are not separated, and they will incur less of the stigma of difference if integrated. 


\section{The Principle of Procedural Due Process}

This principle affords students and their parents rights to mediation, "mandatory resolution meetings," and administrative hearings with appeal to courts in the event of any change in eligibility/classification, program, placement, or provision of a free appropriate public education (20 U.S.C. Sec. 1415).

A logical amendment to NCLB would be to require FBA, $\mathrm{BIP}$, and individualized PBS whenever any student is subjected to "long-term" discipline (more than 10 days). Of course, if all general education students were to have the same procedural due process rights as students with disabilities, there would be huge "floodgates" and cost challenges, with the practice of "defensive" general education and the encouragement of a "culture of compliance" that might disregard outcomes. A less broadly sweeping approach exits, namely, for Congress to amend NCLB to require IDEA-type procedural safeguards for all students from "diverse" populations and all from comorbid environments. These students are especially vulnerable to education decision making (often pretextual and arguably prejudice-driven decision making) that requires precisely the IDEA procedural due process (National Research Council, 2002; U.S. Department of Education, 2007).

\section{The Principle of Parent Participation}

This principle grants parents rights to participate in their child's evaluation and the development of their child's IEP (20 U.S.C. Sec. 1414(a)-(d)). At the very least, Congress should amend NCLB to require that, whenever any general education student receives significant modifications in the general education curriculum, modifications in the methods of instruction, or individualized services (such as related services or PBS), the student's LEA must notify the student's parents and offer an opportunity to meet and discuss the modifications or services.

Beyond that, Congress should further amend NCLB to assure full IDEA-type parent participation in schools with "diverse" secondary-level students from comorbid environments. These students and their families are the ones who need to be brought far more powerfully under the schools' reach.

\section{TRIFURCATING A BIFURCATED MODEL FOR SUPPORTED EDUCATION, RESTORING CIVIL RIGHTS, AND FOCUSING ON SECONDARY-LEVEL STUDENTS}

The present structure of education and education policy is bifold. There are two structures and two overarching policies: general and special. I propose that we change the typology so there would be three structures:
1. General education for students not needing some unusual support

2. Supported education for nondisabled students needing some unusual support (especially those from "diverse" populations and comorbid environments) and for students now in special education classified as having a specific language disorder, a speech-language impairment, or ADHD

3. Special education for the remaining and limited number of students who need extraordinary supports

\section{The "Enlarged Class" and Dilution}

To justify my "modest" proposal, let me say that, surprisingly, I concur with the criticisms from Finn et al. (2001) and PCESE (2003) that special education has opened itself to a much larger "class" of students than it should have. The increasing number of "categories" and the inclusion of students with relatively mild support needs into special education are indisputable, especially in the categories of specific learning disabilities, speech-language impairments, and ADHD, and, for students from diverse backgrounds, emotional-behavioral and intellectual disabilities (Turnbull et al., 2010; Swanson, 2008; U.S. Department of Education, 2007). This "spread effect" arguably has diluted the power of special educators to make significant differences in children within special education, especially those with more intense support needs (Finn et al.; PCESE).

It is time to stop the "spread" of special education, not, as Finn and PCESE have proposed, by preventing students from entering special education but, rather, by doing that and by creating programs of "supported education" for those who are struggling in general education but not clearly having intense support needs. No single-shot approach, such as by providing for new procedures for evaluating students to determine whether they have a specific learning disability through optional use of the discrepancy standard or the RTI approach (20 U.S.C. Sec. 1414 ((b)(6)), has been effective, in the 5 years since Congress amended IDEA, in holding level, much less decreasing, the number of students classified with those disabilities and served in special education. Under my modest proposal, especially students with specific learning disabilities, speech-language impairments, and ADHD, but also those with low-intensity needs related to their OHI, sensory disabilities, intellectual-developmental and emotional-behavioral disabilities, and many general education students who have been screened and might be placed into special education would be enrolled in the supported education programs, receiving education and other human services according to their needs.

The supported education approach, then, would retain many students in general education who otherwise would have been made eligible for special education, support in 
general education's supported education programs the students who otherwise would have been made eligible for special education, and reduce the number of students in special education.

To begin the three-tiered system, I propose using three approaches:

1. Part C eligibility: If a student has or has a risk of having a developmental delay, the student may qualify for supported education if general education does not enable the student to progress but special education is too restrictive or stigmatizing.

2. Diversity and comorbidity: if the student is from a "diverse" population, a comorbid environment, the student may qualify.

3. Age: If the student is in or about to enter secondary school, the student will qualify.

None of these students will qualify for supported education until after the student receives an individualized evaluation that the student will benefit from support but does not need special education. The evaluation should be consistent with IDEA's whole-child, nondiscriminatory approach.

\section{Intensities of Support}

Just as the widely accepted model of PBS now is school wide and has three levels or tiers of intervention (general, group, and individual), so, too, should our entire structure be reshaped to have three, not two, service systems. That change would reflect (1) the approach used by the American Association on Intellectual and Developmental Disabilities (AAIDD, 2010) - a supports intensity approach; (2) the Kansas approach of multi-tiered systems of support; (3) the RTI prevention-intervention approach; and (4) School-wide PBS (SWPBS).

\section{ADA/504 Consistency}

The supported-education model is not inconsistent with the approach that ADA and Sec. 504 take: If the student has a disability (need for support) but needs only "reasonable accommodations," the student does not qualify for special education but does qualify for reasonable accommodations. Similarly, the students I identified above will qualify for supported education-that is, interventions comparable to reasonable accommodations but without the classification of having a disability.

\section{Reinvigorating the Civil Rights Movement through Multi-Domained Evaluations and Multi-Tiered Support Structures and Services}

NCLB should provide specially for students from populations that are more directly affected by the new morbidity.
It should more directly return to the equal protection origins/civil rights origins of IDEA and issues of misclassification. NCLB now correctly targets Title I ("povertyaffected") schools but misfocuses on the students' academic progress to the exclusion of their emotional, social, and civic development. Unlike IDEA, which evaluates a child's needs from multiple perspectives - cognitive, developmental, functional, and emotional-behavioral, NCLB uses academic progress (as determined by the state and local assessments) as the only measure for school success.

True, academic progress can be a proxy for progress in the child's other domains, but those other domains are neglected-a deliberate, statutory neglect. I propose that Congress amend NCLB to provide for evaluation of students from the at-risk/correlation populations according to the same four domains that IDEA now uses, and then to require the types of support that I have suggested-a three-tiered structure with increasing intensity of support.

\section{Abandon the Agrarian Model}

American students attend school for less time and for fewer days than students in emerging nations with which we must compete economically, technologically, diplomatically, and (we hope not) militarily. It is time to increase the length of our school days and the number of days that students attend school. Let the optional "early periods" become mandatory; let the occasional and sometimes optional "after-school" programs become regular and mandatory; increase the number, salaries, and benefits of teachers, related service personnel, and other support staff; and recognize that the human investment we make now is far cheaper to individuals and the nation than ignorance and less than fully competent individuals.

\section{Declare and Educate to Explicit Outcomes}

IDEA (20 U.S.C. Sec. 1401(c)) seeks four outcomes: (1) equal protection (without which the other outcomes are unattainable), (2) independent living (including the training and support to make autonomous decisions), (3) full participation (a concept of citizenship, not just "being in"inclusion and integration), and (4) economic self-sufficiency. NCLB should explicitly seek comparable outcomes: All students in general education and supported education will be educated sufficiently to appreciate and exercise the rights, privileges, and duties of citizenship; to advance to postsecondary education; to perform effectively in the national economy; and to contribute to the well-being of others. It should affirm "great expectations" and then rebrand, restructure, retool, reboot, and restart education for marginalized students and their families, using IDEA as the model. 


\section{Rename}

I propose that Congress should drop "No Child Left Behind" as a title for the new ESEA. It expresses a negative concept-don't do what we have always done-and replace it with a positive: "Become All You Can Be" (a modification of the U.S. Army's slogan, "Be All You Can Be"), or (less militarily but more clumsily), "Advancing All Students' Fullest Potential."

\section{Decentralize}

In the late 1960s, "decentralization" of school was a popular approach to governance. It resonated in the civil rights movement and reflected distrust that sadly sometimes took the form of urban riots. Today, decentralization obtains in other forms: charter schools, public subsidy of private and parochial education through vouchers, conversion of large schools into mini-schools housed within a single campus, competitive admission to public schools, and so on. The model of decentralized schools can easily coexist with the reformed tripartite model I suggest; indeed, the smaller the unit of education and the more linked its delivery system is to the needs of an identified population and the more connected it is to services that address the contexts of the students' lives, the more likely we are to have outcomes that satisfy more students and the nation as a whole.

\section{INCENTIVIZE, PHASE-IN, MONITOR REFORM, AND THEN SCALE-UP}

My modest proposal requires caution, because it is not so modest. Here are ways to advance the proposal — but still be cautious.

- Authorize and appropriate for the supported education model.

- Create demonstration programs targeted to "diverse" and comorbid affected secondary schools.

- Provide special aid to SEAs and LEAs that apply to operate 5-year demonstration grants.

- Limit the grants to LEAs in which the correlates of disability are high.

- Establish outcomes (fewer students referred and made eligible for special education, more retained in general and supported education, progress across four domains).

- Assure regular independent evaluation and reports.

- Plan scaling-up within states with demonstration grants.

- Plan start up and scaling-up within all other states.

\section{Empower Parents}

It is right to retain the Parent Information and Resource Centers that NCLB authorizes and the Parent Training and Information Centers that IDEA authorizes. But now it is time to create a national system of Community-Based Resource Centers, providing for at least one in every school district where there is a Title I school, if not in each state; and to merge (or at least align the functions and missions of) the PIRCs, PTIs, and CPRCs so the power of each augments the power of each other, the sum becoming greater than the whole of the parts.

\section{Enact a Part D for NCLB}

Just as in IDEA, I suggest creating a system capacity that is fueled by federally supported research, training, demonstrations, and technical assistance. Accordingly, the supported education model would have its own "Part D," which would create research, training/personnel prep, and technology programs comparable to those of Part D but targeted to the "supported education" students, professionals, and families.

\section{Fund Legal Services and P\&A}

There are no rights without revenues, no rights without remedies, and no remedies without advocates. So Congress should appropriate more funds to the state Protection and Advocacy Centers (Disability Rights Networks/Centers), the Legal Services Corporation, and to other entities, such as public interest law firms, that are qualified to use legal processes to enforce students' and parents' rights in IDEA and ESEA/Supported Education.

\section{BE BRAVE}

Let us return to Jonathan Swift. You may recall that he was author of not only A Modest Proposal but also Gulliver's Travels (1726, amended 1735). A cleric, he nevertheless was a satirist. In both roles he had an author's liberty of creativity grounded in, first, theology, and, second, reality.

I am hardly Jonathan Swift, Jr. But as an observer of special education policy ever since I wrote my first essays about this in the mid-1970s and as a tenured professor, protected from all but the judgment of my peers, I, too, have a modest license to make immodest proposals. In my judgment, it is time for the special education community, in collaboration with the general education community and the civil rights community, bravely to consider somewhat radical changes in policy and thus the outcomes for various students and families and for the country as a whole. If fortune favors the brave, as I have been taught, it is time for bravery. We have not been as fortunate as we need to be.

\section{REFERENCES}

American Association on Intellectual and Developmental Disabilities (AAIDD). (2010). Intellectual Disability: Definition, Classification, and Systems of Support. Washington, DC: Author. 
Americans with Disabilities Act, 42 U.S.C. Sec. 12101 et seq.

$B d$. of Ed. v. Rowley, 458 U.S. 176 (1982).

Biederman, J. (2005). Attention deficit/hyperactivity syndrome: A selective overview. Biological Psychiatry, 57(11), 1215-1220.

Brown v. Board of Education, 349 U.S. 886 (1954)

Civil Rights Act of 1964 (PL 102-166, 42 U.S.C. Sec. 1971).

Egger, H. L., Kondo, D., \& Angold, A. (2006). The epidemiology and diagnostic issues in preschool attention-deficit/hyperactivity disorder. Infants \& Young Children, 19(2), 109-122.

Finn, C., Rotherham, A., \& Hokanson, C. (2001). Rethinking special education for a new century. Washington, DC: Fordham Foundation.

Individuals with Disabilities Education Act, 20 U.S.C. Sec. 1401 et sec.

Larry P. v. Riles, 793 F. Supp. 969, 1984 U.S. App. LEXIS 26195 (1984, giving full history of case dating back to the early 1970s) No Child Left Behind Act of 2001, PL 107-110.

National Center for Educational Statistics (NCES). (2009). The Condition of Education, 2009. Retrieved November 2, 2009, from http://nces.ed.gov/programs/coe/statement.index.asp

National Research Council (2002). Minority students in special and gifted education. Washington, DC: National Academy Press

Ong-Dean, C. (2009), Distinguishing disability: Parents, privilege, and special education. Chicago: University of Chicago Press.

Parents in Action in Special Education (PASE) v. Hannon, No. 74-C3586 (N.D. Ill., 1980).

President's Commission on Excellence in Special Education (2002, July). A new era: Revitalizing special education for children and their families. Washington, DC: Author.

Rehabilitation Act of 1973 as amended in 1974, 29 U.S.C. Sec. 794 (commonly known as Sec. 504 of PL 93-651, the 194 amendment)
Schumaker, J. B., Deshler, D. D., Bulgren, J. A., Davis, B., Lenz, K. B., \& Grossen, B. (2002). Access of Adolescents with Disabilities to General Education Curriculum: Myth or Reality? Focus on Exceptional Children, 35(2), 3.

Smith, B.H., Barkely, R.A. \& Shapiro, C. J. (2007). Attention-deficit/ hyperactivity disorder. In E. J. Marsh \& R.A. Barkely (Eds.). Assessment of childhood disorders (4th ed., pp. 53-122). New York: Guilford Press.

Swanson, C. B. (2008). Special education I America: The state of students with disabilities in the nation's high schools. Bethesda, MD: Education Research Center.

Turnbull, H. R., Stowe, M. J., \& Huerta, N. E. (2007, revised printing). Free appropriate public education: The law and children with disabilities. Denver, CO: Love.

Turnbull, A., Turnbull, R., \& Wehmeyer, M. L. (2010). Exceptional Lives: Special Education in today's schools. Saddle River, NJ, and Columbus, $\mathrm{OH}$ : Pearson.

Turnbull, H. R., III, \& Turnbull, A. P. (1978). Free Appropriate Public Education: Law and Implementation. Denver, CO: Love.

Turnbull, H.R., \& Wheat, M. J. (1983). Legal Responses to Classification. In Matson, J. L., \& Mulick, J. A. (Eds.). Handbook of mental retardation. New York: Pergamon Press.

U.S. Department of Education (2007). The 26th Annual Report to Congress on the Implementation of the Individuals with Disabilities Education Act, Vol. 1. Washington, DC: Author

West, J. E. \& Whitby, P. J. S. (2008). Federal policy and the education of students with disabilities: Progress and the path forward. Focus on Exceptional Children, 40(3) 1-16. 


\section{LOVE PUBLISHING COMPANY ${ }^{\circledR}$}

\section{Teaching Students with Behavior Disorders}

\section{Techniques and Activities for Classroom Instruction - Third Edition}

\section{Patricia A. Gallagher}

The content in this book for teaching and managing elementary to eight grade students includes vignettes, curriculum topics and instruction, educational diagnoses, and positive management programs to help children with behavior disorders.

You will find 12 strategies for general and special education teachers to help students achieve academic and social success along with 10 psychological variables in the classroom environment that impact student behavior. Based on

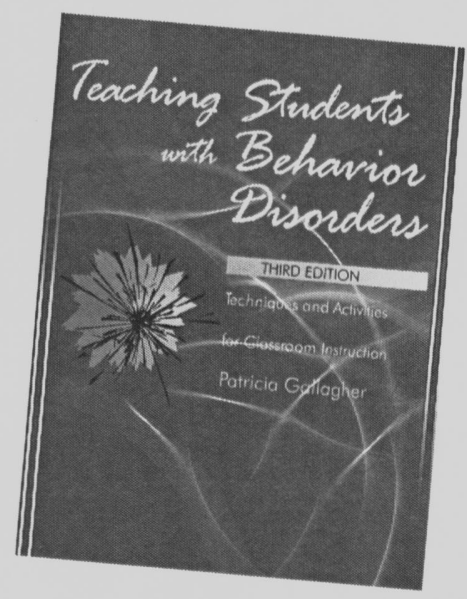
a perspective combining psychoeducation, behaviorism, and structure, the book contains classroom examples, forms, and illustrations. It is a warm and inviting book containing workable ideas to help troubled children succeed.

\section{Contents}

1. Troubled Youth: An Overview

2. Directions for Planning Academic and Behavior Success

3. Organization of the Physical Environment

4. Educational Diagnosis

5. Curriculum: Basic Considerations

6. Curriculum: Instructional Techniques

7. Curriculum: Essential Topics for Instruction

8. Responses to Students with Specific Needs

9. Management: Overview

10. Management: Affective Techniques

11. Management: Behavior Techniques

12. Management: Decision-Making Techniques

13. Communication with Significant Adults

Appendix A: Vignettes

Appendix B: Promoting Dignity: Taking the Destructive Ds out of Behavior Disorders 


\section{INDEX ・ Volume 41}

\section{Author Index}

Batchelder, Heather W. (April 2009)

Cross, Lee (April 2009)

Crowley, E. Paula (December 2008)

Dopson-Campuzano, Natalie (April 2009)

Ford, Donna Y. (May 2009)

Gagnon, Joseph C. (September 2008)

Greer, Diana (January 2009)

Guetzloe, Eleanor (December 2008)

Hoffman, Amanda V. (March 2009)

Johns, Beverly H. (December 2008)

Kea, Cathy D. (May 2009)

Malmgren, Kimber W. (February 2009)

Mastropieri, Margo A. (October 2008)

McLaughlin, Margaret J. (March 2009)

Meyen, Edward (January 2009)

Okolo, Cynthia M. (October 2008)

Rockwell, Sarah B. (September 2008)

Salazar, Marisa J.(April 2009)

Scott, Terrance M. (September 2008)

Scruggs, Thomas E. (October 2008)

Trezek, Beverly J. (February 2009)

West, Jane E. (November 2008)

Whitby, Peggy J. Schaefer (November 2008)

Wilson, Michael G. (March 2009)
Chronological Index of Titles

Positive Behavior Supports in Exclusionary Schools: A Practical Approach Based on What We Know (September 2008)

Science and Social Studies for Students With Disabilities (October 2008)

Federal Policy and the Education of Students with Disabilities: Progress and the Path Forward (November 2008)

Engaged Time in the Classroom (December 2008)

The Role of Instructional Planning in Math Instruction for Students With Learning Disabilities (January 2009)

Literacy Instruction for Secondary Students with Disabilities (February 2009)

Preparing Youth with Disabilities for College: How Research Can Inform Transition Policy (March 2009)

Best Practices and Considerations: Including Young Children with Disabilities in Early Childhood Settings (April 2009)

Creating Culturally Responsive Instruction: For Students' and Teachers' Sakes (May 2009)

\section{PERMISSIONS AND COPYRIGHT}

All rights are reserved. No part of this publication may be reproduced, photocopied, faxed, stored in a retrieval system, or transmitted in any form or by any means, electronic, mechanical, recording or otherwise, without the prior written permission of the publisher.
Back issues are available for sale. Reproduction requires permission and payment of fees. It is illegal and a violation of federal copyright law to reproduce this publication without permission. Direct all inquiries to the permissions editor. 